NBER WORKING PAPER SERIES

\title{
BORDER DELAYS AND TRADE LIBERALIZATION
}

\author{
Edgar Cudmore \\ John Whalley
}

Working Paper 9485

http://www.nber.org/papers/w9485

\author{
NATIONAL BUREAU OF ECONOMIC RESEARCH \\ 1050 Massachusetts Avenue \\ Cambridge, MA 02138 \\ February 2003
}

\begin{abstract}
We are grateful to the Gorbachev Foundation for grant support, and to Natalia Tourdyeva, Ksenia Yudaeva and Konstantin Kozlov at CEFIR, Katrin Kuhlmann at STR, and Konstantine Loukine at IDRC for comments, data and discussion. The views expressed herein are those of the authors and not necessarily those of the National Bureau of Economic Research.

(C)2003 by Edgar Cudmore and John Whalley. All rights reserved. Short sections of text not to exceed two paragraphs, may be quoted without explicit permission provided that full credit including notice, is given to the source.
\end{abstract}


Border Delays and Trade Liberalization

Edgar Cudmore and John Whalley

NBER Working Paper No. 9485

February 2003

JEL No. F1, D5, P3

\section{$\underline{\text { ABSTRACT }}$}

Delays at the border for customs clearance are seemingly a central feature of the trade regime in the CIS states. Here, we argue that with queuing costs being endogenously determined in such circumstances tariff liberalization (even in the small economy case) can be welfare worsening since tariff revenues are replaced by resource using queuing costs. On the other hand, corruption can be welfare improving if queuing costs are replaced by resource transferring bribes. We also show how added distortions between perishable and non-perishable, or between light and heavy goods can also arise. We show these outcomes using a simple general equilibrium model, and explore the numerical implications using Russian data. The orders of magnitude are both significant and opposite in sign to conventional analyses.

Edgar Cudmore Department of Economics Social Science Centre University of Western Ontario London, Ontario, Canada N6A 5C2

elcudmor@uwo.ca
John Whalley

Department of Economics

Social Science Centre

University of Western Ontario

London, Ontario, Canada

N6A 5C2

and NBER

jwhalley@uwo.ca 


\section{Introduction}

In a number of lower income and transitional economies it is common for there to be significant delays at the border when achieving customs clearance. This can be due to complex customs formalities, which sometimes are continually changing, capacity constraints given limited facilities, and/or corruption at the border. In some African economies, there are reported delays of 3-6 months to achieve customs clearance ${ }^{2}$, although this is perhaps extreme.

Our paper begins with the observation that if such delays are significant and the length of the delay is endogenously determined, then trade liberalization through tariff reductions that increases the length of the queue can be welfare worsening. Tariff reductions, as have occurred in the CIS states, thus appear to be bad policy without first addressing customs clearance issues. We show this for small open economy cases in a simple general equilibrium model where there is a physical constraint on the volume of imports which can be admitted. We then analyse extensions where corruption occurs, and finally where some imports are perishable. We apply our analysis to data on Russian trade for the late 1990s, with the results emphasizing the themes that not only is it best to deal with border and administrative delays first before engaging in trade liberalization, but also the quantitative orders of magnitudes for the costs involved can be large.

\footnotetext{
${ }^{2}$ See the recent WTO TPRM Report on Togo (1999) p. 30.
} 


\section{2. $\quad$ A Model of Trade with Border Delays}

The role and significance of border delays for trade liberalization in a number of economies around the world is reflected in anecdotal evidence on their importance in the trade of Russia and other former Soviet Union countries. Hare (2001) in a recent piece on trade policy in CIS transition economies says "It is often asserted that inadequate physical infrastructure - roads, railways, and the like - inhibits trade, though solid evidence for this is lacking. More often, the real barrier to trade is again institutional, taking the form of unreasonable customs delays at many borders in the transition economy region, accompanied by widespread demands for bribes to expedite the movement of goods."

The precise length of these delays and even/or how precisely they arise is unfortunately poorly documented in the literature but their impact on trade is unquestionable. There is some suggestion in the literature that continual changes in customs legislation and uncertainty as to how they are to be implemented is a key factor. Equally, these delays are also thought to reflect the time taken for negotiations between officials and importers over valuation, which it is thought can fall dramatically through the use of negotiation intermediaries. Bribes seem to be involved in this process. These and other issues in the Russian case are discussed in Beilock (2002), and Wolf and Gurgen (2000). Delays in the range of weeks or months for clearance are often claimed in anecdotes, with six weeks being an approximate mean figure suggested to us for Russia in conversations although this varies substantially with the port of entry and transportation mode. 


\section{$\underline{\text { A Simple Model }}$}

The purpose of our paper is to focus on the interactions between border delays and trade liberalization in light of their seeming importance in these cases. We formalize these interactions in a model of a simple pure exchange economy which is small and a taker of prices on world markets and engaged in trade. For expositional simplicity of structure, we assume for now there is no production and all goods are traded (these features can be changed in numerical application). The world prices for the $N$ goods we take as given by the $\bar{\pi}_{i}^{w}$. Tariff rates $t_{i}$ apply to imports ( $t_{i}=0$ for exports), and we assume the direction of trade is predetermined. ${ }^{3}$

In this economy, domestic prices depart from world prices on the import side both due to tariffs and queuing costs at the border $T^{q}(\pi)$. For simplicity, we assume these costs are the same for all goods, and that units for goods are denominated in comparable physical terms (e.g. tons). Thus, if $M$ goods are imported and $(N-M)$ exported, and the direction of trade is unchanged,

$$
\pi_{i}^{d}=\bar{\pi}_{i}^{w}\left(1+t_{i}\right)+T^{q}(\pi) \quad(\mathrm{i}=1 \ldots \ldots \ldots . . \mathrm{M})
$$

$T^{q}$ is assumed to be indexed and so is homogeneous of degree one in $\pi$ and is endogenously determined.

The economy has market demand functions, $\xi_{i}\left(\pi^{d}, R, Q\right)$, and non-negative endowments, $w_{i}$, for each of the $N$ goods, where $\pi^{d}$ denotes the $N$ dimensional vector of domestic commodity prices. $R$ defines tariff revenues, and $Q$ represents endogenously determined queuing costs (denominated in units of the good being imported). These

\footnotetext{
${ }^{3}$ This is a standard assumption in most theoretical trade models, although numerically the direction of trade can change when trade policies change. See Abrego, Riezman, and Whalley (2000) for a recent discussion of the likelihood of this assumption being false in comparisons between free trade, customs unions, and
} 
demand functions are non-negative, continuous, homogeneous of degree zero in $\pi^{d}$ and satisfy Walras Law, i.e., at all price vectors $\pi^{d}$

$$
\sum_{i=1}^{N} \pi_{i}^{d}\left(\xi_{i}\left(\pi^{d}, R, Q\right)-w_{i}\right)=0
$$

Assuming there is a single representative consumer in this economy their budget constraint is given by

$$
\sum_{i=1}^{N} \pi_{i}^{d} \xi_{i}\left(\pi^{d}, R, Q\right)=\sum_{i=1}^{N} \pi_{i}^{d} w_{i}+R-\sum_{i=1}^{M} T^{q}(\pi)\left(\xi_{i}-w_{i}\right)
$$

For simplicity, border delays are assumed to reflect a constraint on the volume of imports that can be processed over the period of time covered by the model (e.g. one year). Thus, for now, we consider this to be a physical constraint rather than one reflecting corruption or other considerations. If $\bar{C}$ represents the administratively determined capacity constraint on imports, then

$$
\sum_{i=1}^{M}\left(\xi_{i}\left(\pi^{d}, R, Q\right)-w_{i}\right) \leq \bar{C}
$$

where R denotes tariff revenues $\sum_{i=1}^{M} \bar{\pi}_{i}^{w} t\left(\xi_{i}-w_{i}\right)_{i}$, and $Q=\sum_{i=1}^{M} T^{q}(\pi)\left(\xi_{i}-w_{i}\right)$ denotes the queuing costs.

In this simple model, if the capacity constraint on imports is binding then queuing costs $T^{q}\left(\pi^{w}\right)$ are determined in equilibrium along with domestic prices $\pi^{d}$, tariff revenues, and domestic demands $\xi_{i}$. The effect of tariff liberalization will be to lower tariff revenues and increase queuing costs. In the case where tariff rates are uniform across commodities, tariff reductions simply generate a corresponding increase in 
queuing costs. Since the latter use real resources, tariff reducing trade liberalization will typically be welfare worsening.

\section{$\underline{\text { Model Extensions }}$}

This simple model can be extended in a number of ways which capture additional mechanisms through which border delays and trade liberalization can interact.

\section{Corruption}

One is the presence of corruption. This can be modelled simply in this framework as the ability of customs officials to extract a bribe for allowing passage of goods. We assume that there is a bound to the bribe, which for simplicity we take to be the ability of an official to send the importer to the back of the line in the event a bribe is not paid. If we assume that officials can only do this once, since otherwise they would reveal themselves as corrupt officials if they repeat the denial of clearance, this means that the bribe that can be extracted by the official is within epsilon of the queuing costs $T^{q}$. For simplicity, we take the bribe paid to equal $T^{q}$, which will now change relative to the no corruption case.

The discussion above suggests that the queuing costs in the formulation above are halved, with bribes making up the remaining difference between world and domestic prices for imports. Thus, if $B$ represents the bribe paid per unit import

$$
\pi_{i}^{d}=\bar{\pi}_{i}^{w}\left(1+t_{i}\right)+T^{q}+B
$$

and by construction $B=T^{q}$. 
This also means that in equation (4) the real resource loss from queuing is halved and exports increase, since fewer export earnings are needed to cover queuing costs. Corruption in this case is thus socially desirable since real resource costs are now partially replaced by a transfer of income to government officials.

\section{Perishability}

A further elaboration on the basic model can be used to show how differential impacts of queuing on different commodities can result. One way this can happen is if perishable commodities are more adversely affected by queuing than non-perishable commodities. Differential impacts of border delays across commodities are the end result with added distortionary costs.

We can capture this by defining a variable $\gamma_{i}$ which represents the fraction of goods

shipped which actually arrive, where $\gamma_{i} \leq 1$, and $\left(1-\gamma_{i}\right)$ is the perish rate for good $i$. We can then make $\gamma_{i}$ a function of the time spent queuing so as to capture the feature that perish rates increase with queuing time.

Thus, for each unit shipped and paid for, only $\gamma_{i}$ units actually arrive; or,

$$
\pi_{i}^{d}=\frac{\pi_{i}^{w}\left(1+t_{i}\right)+T^{q}}{\gamma_{i}}
$$

and

$$
\gamma_{i}=1-\lambda T^{q}
$$

where $\lambda$ is a constant, and so perish rates increase with queuing time.

With this formulation, differential impacts of queuing by commodity result and even uniform tariff liberalization now has differential impacts by good. 


\section{Other Extensions}

Various other extensions to this basic model can also be made, which for space reasons we do not elaborate on in any detail. We can use a model with production rather than a simple pure exchange economy with endowments. We can also incorporate non traded as well as traded goods. Both of these are standard in numerical general equilibrium models of actual economies (see Shoven and Whalley (1992)), although neither changes the basic analytical structure in which queuing costs are endogenously determined.

We can also modify the model set out above for cases in which different commodities incur different queuing costs per unit weight due to differing administrative procedures. This could arise with valuation procedures being more complex for, say, components for electronic products compared to basic commodities such as coal. This can be done by building in different factors of proportionality into the analysis for queuing costs for the various quantities imported. Again, the essential structure of the model remains unchanged. 


\section{Some Calculations Using Russian Data}

Using this simple framework, we have made some calculations using Russian data to explore the possible quantitative orders of magnitude involved with analysis of trade liberalization that incorporate border delays. The delays reported in the Russian case appear to be lengthy and a major restraint on trade. These calculations thus serve to underline the point that if tariff reforms occur with no attention being paid first to administrative considerations and border delays, liberalization can be welfare worsening rather than welfare improving as is usually the case in conventional models rather than providing accurate point estimates of actual impacts. Importantly, they suggest that there are costs rather than benefits from trade liberalization in such cases and they can be substantial.

To apply the model set out above to the Russian case, we use CES demand functions and in addition specify the model so as to also include both a non-traded goods sector and two traded goods so that distortions between perishable and non perishable imports can be analysed. All model variants thus include four goods (an exportable, two importables, and a non traded good).

We use the standard applied general equilibrium modelling approach of calibration to a base case data set, followed by counter factual equilibrium analysis (see Shoven and Whalley (1992)). To make our calculations of the impacts of trade liberalization incorporating border delays we have constructed a benchmark equilibrium data set for Russian trade, consumption, and endowments (taken to equal production) by averaging 
data for 1997,1998 , and $1999^{4}$. These are years during which there was substantial variation in Russian trade performance due to the 1998 financial crisis, and using averages in this way partially mitigates extremes in any one years data. We use tariff data from World Bank sources for $1999^{5}$, which suggests an approximate average tariff rate across all imports of $10 \%$. We assume an average border delay of 3 weeks in customs clearance (6 weeks is the figure often claimed). This is the basis for an approximate estimate that with non-delay shipping times from Western Europe of 3 days and formal transportation cost in the range of 5\% (see Hummels (1999) for a recent discussion of the size of transportation costs in trade), delay costs could be in the range of $30 \%$ of the value of imports. We use this estimate as the base case value in our computations, making some modifications in the perishability case.

We use calibration methods and this data to determine both share and elasticity parameters in preferences. For the case of CES preferences, demands are given by

$$
X_{i}=\frac{\alpha_{i} I}{\left(\pi_{i}^{d}\right)^{\sigma} \sum_{j=1}^{N} \alpha_{j}\left(\pi_{j}^{d}\right)^{1-\sigma}} \quad(i=1 \ldots . . N)
$$

where $\alpha_{i}$ are CES shares, $\sigma$ is the substitution elasticity, and income, $I$, is given by

$$
I=\sum_{i=1}^{N} \pi_{i}^{d} w_{i}-\sum_{i=1}^{M} T^{q}\left(\bar{\pi}_{i}^{w}\right)\left(\xi_{i}-w_{i}\right)
$$

In this case, the import demand elasticity, $\eta_{i}^{m}$, for import good $i$ is given by

$$
\eta_{i}^{m}=\left(-\sigma-S_{i}(1-\sigma)\right) \frac{X_{i}}{\left(X_{i}-W_{i}\right)} \quad(i=1 \ldots . . N)
$$

\footnotetext{
${ }^{4}$ Data on trade and consumption are taken from the 2001 World Development Indicators. Data on production by industry (which we use to represent endowments) originates from Goskomstat sources and we are thankful to Natalia Tourdyeva for providing it for us.

${ }^{5}$ Data on tariff rates are taken from the 2001 World Development Indicators, published by the World Bank.
} 
where $S_{i}$ is the income expenditure share on good $i$.

These elasticities are not constant and so direct calibration is not possible. The convention in calibration literature is to use a literature estimate and choose $\sigma$ so that the implied point estimate of the elasticity in the neighbourhood of the benchmark equilibrium is literature consistent. If share parameters on imported goods are large, then negative values of $\sigma$ can result from calibration if import demand elasticities in the neighbourhood of one are used. This is common in general equilibrium trade models, since the majority of estimates in the literature are around one (see Erkel-Rousse and Mirza (2002)). Not recognizing the significance of non traded goods can result in this problem since expenditure shares on traded goods are smaller in models with non traded goods than without them, and is one reason for including them in the model.

Using GAMS(1996) solution software, we calibrate both the basic model and associated variants to the averaged 1997-1999 benchmark data set. We then evaluate the effects of tariff reform for each model variant by computing counterfactual equilibria which we also compare to the base case. We also use a model variant where no border delays are present, which we term the conventional case. In this event, gains from tariff liberalization occur.

We classify the trade data into importables and exportables based on the sign of net trade flows by commodity. We use equation (5) to calibrate model share parameters from data on consumption and prices, choosing units for goods in the model such that world prices are one. Equation (5) is used jointly in calibration with equation (6) which determines $\sigma$ given shares, once import price elasticity values are assumed. ${ }^{6}$ Our

\footnotetext{
${ }^{6}$ We calibrate to the import price elasticity of the first import good, and since share parameters on the two imports are similar these two import price elasticities are very close.
} 
calibrations yield share and elasticity parameter estimates for the basic model variants for assumed values of import price elasticities lying between -1 and -2 (one is the most frequently used in empirical trade models) as set out in Table 1.

Using models parameterized in this way, we have generated two sets of results which allow us to analyse the interactions between trade liberalization and border delays. In Table 2, we show welfare and trade impacts of liberalization in the basic model with border delays and in two model extensions which incorporate corruption and perishability. These estimates are reported for the three values of assumed import price elasticities used in calibration in Table 1.

\section{Table 1}

\section{Calibrated Basic Model Parameters From 1997-1999 Russian Data}

\begin{tabular}{|l|c|c|c|c|c|}
\hline Assumed & \multirow{5}{*}{$\begin{array}{c}\sigma \\
\text { Import Price }\end{array}$} & \multicolumn{4}{|c|}{ Share Parameters in Preferences } \\
\cline { 3 - 6 } Elasticity & $\begin{array}{c}\text { Generated by } \\
\text { Calibration }\end{array}$ & \multicolumn{2}{|c|}{ imported goods } & exportables & non-traded goods \\
\hline-1.0 & 0.314 & 0.260 & 0.220 & 0.068 & 0.452 \\
\hline-1.5 & 0.676 & 0.276 & 0.234 & 0.064 & 0.426 \\
\hline-2.0 & 1.038 & 0.293 & 0.248 & 0.060 & 0.399 \\
\hline
\end{tabular}

Results in Table 2 show negative welfare effects of trade liberalization measured in terms of the Hicksian equivalent variation as a percentage of income in all cases. These costs become larger as the assumed price elasticity rises since as both substitution elasticities and share parameters change the evaluation of utility pre and post liberalization changes. Larger impacts on queuing costs across these cases reflect the different share parameters generated by calibration. Costs are smaller in the with corruption cases, for high elasticities and larger for smaller elasticities. The real resource 
costs from queuing in corruption cases are approximately one half of those in no corruption cases, and in that sense corruption is good in the model. But changes in queuing costs are comparable. Perishability raises costs slightly for all import price elasticity cases. Import volumes only change in the perishability cases.

\section{Table 2}

Impacts of Trade Liberalization in Russia in the Presence of Border Delays; models calibrated to averaged 1997-1999 data

\begin{tabular}{|c|c|c|c|}
\hline & $\begin{array}{c}\text { Basic } \\
\text { Model with } \\
\text { border } \\
\text { delays }\end{array}$ & $\begin{array}{l}\text { Extended } \\
\text { Model with } \\
\text { corruption }\end{array}$ & $\begin{array}{l}\text { Extended Model with } \\
\text { perishability }\end{array}$ \\
\hline \multicolumn{4}{|l|}{ A. Import Price Elasticity $=-1$} \\
\hline $\begin{array}{l}\text { Welfare gain/loss as Hicksian } \\
\text { EV as } \% \text { of income }\end{array}$ & -0.130 & -0.146 & -0.134 \\
\hline $\begin{array}{l}\text { - Impacts on import volumes } \\
\text { (\%change })\end{array}$ & 0 & 0 & $\begin{array}{c}-0.078(\text { perishable }) \\
0.017 \text { (non perishable) }\end{array}$ \\
\hline $\begin{array}{l}\text { - Impacts on export volumes } \\
\text { (\%change })\end{array}$ & 0.711 & 0.920 & 0.723 \\
\hline \multicolumn{4}{|l|}{ B. Import Price Elasticity $=-\mathbf{1 . 5}$} \\
\hline $\begin{array}{l}\text { Welfare gain/loss as Hicksian } \\
\text { EV as \% of income }\end{array}$ & -0.248 & -0.245 & -0.253 \\
\hline $\begin{array}{l}\text { Impacts on import volumes } \\
(\% \text { change })\end{array}$ & 0 & 0 & $\begin{array}{c}-0.431 \text { (perishable) } \\
0.095 \text { (non perishable) }\end{array}$ \\
\hline $\begin{array}{l}\text { - Impacts on export volumes } \\
(\% \text { change })\end{array}$ & 1.361 & 1.550 & 1.369 \\
\hline \multicolumn{4}{|l|}{ C. Import Price Elasticity $=-2$} \\
\hline $\begin{array}{l}\text { Welfare gain/loss as Hicksian } \\
\text { EV as \% of income }\end{array}$ & -0.343 & -0.310 & -0.347 \\
\hline $\begin{array}{l}\text { - Impacts on import volumes } \\
(\% \text { change })\end{array}$ & 0 & 0 & $\begin{array}{c}-0.989 \text { (perishable) } \\
0.217 \text { (non perishable) }\end{array}$ \\
\hline $\begin{array}{l}\text { - Impacts on export volumes } \\
\text { (\%change })\end{array}$ & 1.887 & 1.969 & 1.883 \\
\hline
\end{tabular}


The second set of results in Table 3 compares those from the basic model with border delays to those from a more conventional model with no border delays. To make this comparison, we use a case for a conventional tariff model where there are no queuing costs in the base case, so that in this model relative price effects of tariff liberalization come into play as tariffs are eliminated and no queuing costs enter. In the comparable border delay model, the capacity constraint on imports remains. A tariff equal to the combined queuing plus tariff wedge in the base model is applied to the conventional model. We then consider a reduction in this tariff by 10 percentage points. In both of these cases, we use an import price elasticity of minus one in calibration. As Table 3 indicates, the signs of welfare effects are reversed between models, and the absolute values of effects are different.

Table 3

\section{Comparing result of trade liberalization in Russia using a conventional model} and one incorporating border delays, averaged 1997-1999 data

\begin{tabular}{|c|c|c|}
\hline & $\begin{array}{c}\text { Conventional Model } \\
\text { (No border delays) }\end{array}$ & $\begin{array}{c}\text { Basic Model with } \\
\text { border delays }\end{array}$ \\
\hline \multicolumn{3}{|l|}{ Import Price Elasticity $=-1$} \\
\hline $\begin{array}{l}\text { - Welfare gain/loss as Hicksian } \\
\text { EV as \% of income }\end{array}$ & 0.044 & -0.130 \\
\hline $\begin{array}{l}\text { - Impacts on import volumes } \\
\text { (\%change) }\end{array}$ & 0.931 & 0 \\
\hline $\begin{array}{l}\text { - Impacts on export volumes } \\
\text { (\%change) }\end{array}$ & 0.614 & 0.711 \\
\hline
\end{tabular}

These simulation results thus clearly show how trade liberalization can be welfare worsening in the presence of border delays. Tariff reductions have little or no impact on domestic prices because of the capacity constraint on processing imports. More queuing results in added real resource costs, rather than generating revenues as is true with tariffs. 
The presence of corruption tends to weaken these effects since lowered tariffs now increase transfers to corrupt officials with smaller effects on aggregate incomes. Perishability considerations affect the costs of liberalization through more product loss, and added queuing results. And the differences relative to a conventional trade liberalization model are in sign.

In sum, this analysis and the simulations reported point to the significant role that border delays can play in influencing the effects of trade liberalization. Without prior attention to administrative procedures and customs clearance, trade liberalization can become welfare worsening by increasing queuing costs. Trade liberalization in CIS states that does not first deal with administrative delays can thus be viewed as potentially counterproductive. 


\section{4. $\quad$ References}

Abrego L., R. Riezman, J. Whalley (2001) "How Reasonable are the Assumptions Used in Theoretical Models?: Computational Evidence of the Likelihood of Trade Pattern Changes". NBER \#W8169, March 2001.

Beilock R. (2002) “Will New Roads Help? Institutional Barriers to International Transport in Eastern Europe and the CIS" mimeo, University of Florida

Clarete R. and J. Whalley (1991) "Foreign Exchange Premia and Non-Neutrality of Monetary Policy in General Equilibrium Models" Journal of International Economics, Vol. 30, pp 153-166.

Erkel-Rousse H. and D. Mirza (2002) "Import price elasticities: reconciling the evidence" Canadian Journal of Economics, Vol. 35, No. 2, May pp 282-306.

Hare P. G. (2001) “Trade Policy During the Transition: Lessons from the 1990's" The World Economy, Vol. 24, No. 4, April.

Hummels, David (1999) “Have International Trade Costs Declined?” (mimeo) University of Chicago.

Shoven, J. B. and J. Whalley (1992) Applying General Equilibrium, Cambridge University Press.

Wolf T. and E. Gurgen (2000) "Improving Governance and Fighting Corruption in the Baltic and CIS Countries: The Role of the IMF" Economic Issues, No. 26, International Monetary Fund, Washington, D.C.

WTO (1999). Trade Policy Review: TOGO 1999. WTO Publications Switzerland. 